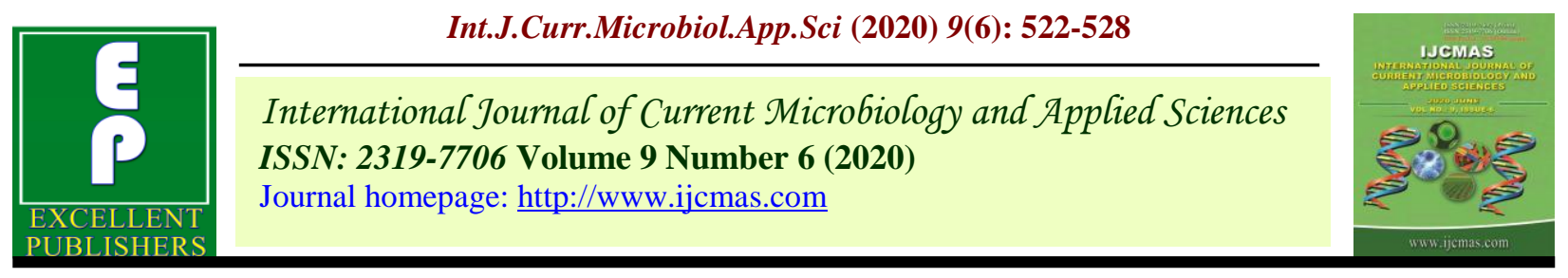

Original Research Article

https://doi.org/10.20546/ijcmas.2020.906.067

\title{
Performance of Green Manures and Phosphorus Levels in Rice-Blackgram Cropping Sequence
}

\author{
K. Anny Mrudhula*, Ch. PullaRao, B. Venkateswarlu, \\ P.R.K Prasad and Y. Ashoka Rani \\ Department of Agronomy, Agricultural College, Bapatla \\ *Corresponding author
}

\begin{tabular}{|l|}
\hline Ke y w o r d s \\
$\begin{array}{l}\text { Blackgram crop, } \\
\text { sandy clay loam } \\
\text { soil, green manure }\end{array}$ \\
\hline Article Info \\
\hline $\begin{array}{l}\text { Accepted: } \\
\text { 15 May 2020 } \\
\text { Available Online: } \\
\text { 10 June } 2020\end{array}$ \\
\hline
\end{tabular}

\section{A B S T R A C T}

A field experiments was conducted during 2015 and 2016 to study the effect of green manures and phosphorus levels in blackgram crop at Agricultural College Farm, Bapatla. The experiment was conducted in split- split plot design on sandy clay loam soil with three main treatments three sub-treatments tokharif rice and three sub-sub treatments to rabi crop. The treatments consisted of dhaincha green manure crop, sunnhemp green manure crop and without green manure as main plot treatments and three phosphorus levels to rice crop comprising of $45 \mathrm{~kg} \mathrm{P}_{2} \mathrm{O}_{5} \mathrm{ha}^{-1}, 60 \mathrm{~kg} \mathrm{P}_{2} \mathrm{O}_{5} \mathrm{ha}^{-1}$ and $75 \mathrm{~kg} \mathrm{P}_{2} \mathrm{O}_{5} \mathrm{ha}^{-1}$ as sub- plot treatments and are replicated thrice. The rabi experiment was laid out on the same site in a split-split plot design without disturbing the soil for succeeding blackgram crop and each of the kharif plot was divided into three sub-sub plots to receive three levels of phosphorus (No P, 50\% RDP and 100\% RDP) to each plot. Growth parameters, yield attributes and yield of blackgram which received dhaincha green manure incorporation with $75 \mathrm{~kg} \mathrm{P}_{2} \mathrm{O}_{5}$ ha $^{-1}$ to kharif rice crop and $100 \%$ RDP to rabi blackgram was recorded significantly higher and it was on a par with sunnhemp green manure incorporation with $75 \mathrm{~kg} \mathrm{P}_{2} \mathrm{O}_{5} \mathrm{ha}^{-1}$ to kharif rice crop and $100 \%$ RDP to rabi blackgram.

\section{Introduction}

India has the largest area under pulses in the world with the area is about 190.4 lakh hectares producing 124.0 lakh tonnes with an average yield of $651.2 \mathrm{~kg} \mathrm{ha}^{-1}$. Among the pluses, blackgram (Urdbean) contributes $16.28 \%$ of the total area and $11.48 \%$ of the total production with an average productivity of $451.6 \mathrm{~kg} \mathrm{ha}^{-1}$. Nutrient management is an important aspect in increasing the productivity of pulses. Phosphorus is a key nutrient for increasing productivity of pulses
(Deo and Khaldelwal, 2009). The adequate supply of phosphorus to legume is more important than that of nitrogen, because it has beneficial effect on root development, nodulation, growth and yield.

A large portion of phosphorus remaining after the first crop is not fixed but is indeed available to the subsequent crops (Kundu et $a l$. , 1986). Incorporation of green manures along with fertilizers leads to increased productivity of the system and sustained health for longer period. 
Hence, the available literature on green manures, $\mathrm{P}$ levels and their residual effect on succeeding blackgram is meager, the present investigation was carried out with a view to evaluate the effect of phosphorus levels to kharif crop and phosphorus doses to rabi blackgram in rice-blackgram cropping sequence.

\section{Materials and Methods}

A field experiment was conducted during 2015 and 2016 at Agricultural College Farm, Bapatla to study the effect of green manures and phosphorus levels to kharif crop and phosphorus doses to blackgram crop. The experiment was conducted in split plot design on sandy clay loam soil with three main treatments and three sub-treatments during kharif season and split-split plot design in Rabi season.

The treatments consisted of dhaincha green manure crop, sunnhemp green manure crop and without green manure as main plot treatments and three phosphorus levels to rice crop comprising of $45 \mathrm{~kg} \mathrm{P}_{2} \mathrm{O}_{5} \mathrm{ha}^{-1}, 60 \mathrm{~kg}$ $\mathrm{P}_{2} \mathrm{O}_{5}$ ha $^{-1}$ and $75 \mathrm{~kg} \mathrm{P}_{2} \mathrm{O}_{5} \mathrm{ha}^{-1}$ as sub- plot treatments and are replicated thrice.

The rabi experiment was laid out on the same site in a split-split plot design without disturbing the soil for succeeding blackgram crop and each of the kharif plot was divided into three sub-sub plots to receive three levels of phosphorus (No P, 50\% RDP and 100\% RDP) to each plot.

Nitrogen, phosphorus and potassium were applied through urea, single super phosphate and murate of potash, respectively. Recommended agronomic management practices and plant protection measures were followed during crop growth periods. The data recorded and were analyzed the following standard statistical analysis.

\section{Results and Discussion}

\section{Plant height (cm) of blackgram}

The plant height at harvest was significantly influenced by green manures incorporated and $\mathrm{P}$ levels to rice crop as well as $\mathrm{P}$ application to succeeding rabi blackgram during both the years of study. The maximum plant height of blackgram was recorded when the preceding rice was incorporated with dhaincha green manure @ $75 \quad \mathrm{~kg} \quad \mathrm{P}_{2} \mathrm{O}_{5} \mathrm{ha}^{-1}$ and found significantly superior to control at $45 \mathrm{~kg} \mathrm{P}_{2} \mathrm{O}_{5}$ $\mathrm{ha}^{-1}$ during both the years of study. Significantly the highest plant height (76.3 and $81.1 \mathrm{~cm}$ during $1^{\text {st }}$ and $2^{\text {nd }}$ year respectively) at harvest was noticed with $100 \%$ phosphorus dose to blackgram, which was significantly superior to control. However, the treatments with $50 \%$ and $100 \%$ RDP were on a par with each other. But, the lower plant height $(70.7$ and $77.1 \mathrm{~cm})$ was registered by control. The beneficial effect of phosphorus through the availability of higher energy in the form of ATP molecules which might have favoured multiplication of cells enhancing the plant height there by increases the drymatter production was also reported by several researchers like Hanumanthappa and Hosamani 1989.

\section{Drymatter accumulation $\left(\mathrm{g} \mathrm{m}^{-2}\right)$ of blackgram at harvest}

Drymatter production of rabi blackgram was significantly higher (1852 and $1855 \mathrm{~kg} \mathrm{ha}^{-1}$ ) when its preceding rice crop was incorporated with dhaincha green manure followed by sunnhemp green manure (1847 and $1845 \mathrm{~kg}$ $\mathrm{ha}^{-1}$ ) incorporation. Significantly the highest drymatter accumulation of rabi blackgram in both the years of study was recorded when its preceding rice was applied with $75 \mathrm{~kg}_{2} \mathrm{O}_{5}$ $\mathrm{ha}^{-1}$. The lower drymatter was recorded when the kharif rice was supplied with $45 \mathrm{~kg} \mathrm{P}_{2} \mathrm{O}_{5}$ $\mathrm{ha}^{-1}$ in both the years of study (Table 1). 
Where, it was statistically comparable with 60 $\mathrm{kg} \mathrm{P}_{2} \mathrm{O}_{5} \mathrm{ha}^{-1}$ during both the years of study. Phosphorus availability was more at higher levels of phosphorus to blackgram crop. There was a gradual increase in the drymatter accumulation of rabi blackgram with increase in phosphorus application to it during the first and second years of study. The higher drymatter accumulation of rabi blackgram was recorded with $100 \%$ RDP application (1862 and $1861 \mathrm{~kg} \mathrm{ha}^{-1}$ ) and was significantly superior to control only. The lower drymatter was registered in the control (1769 and 1745 $\mathrm{kg} \mathrm{ha}{ }^{-1}$ ) during both the years of study. Applications of higher levels of phosphorus to the previous crop lead to higher residual phosphorus to the second succeeding crop. This might be the reason for the significant difference in the drymatter accumulation of rabi blackgram. Increased drymatter production might be due to the positive effect of phosphorus on proliferation of root system resulting in increased nutrient uptake as opined by Ajay and Vinod (2006).

\section{Number of pods plant ${ }^{-1}$}

During both the years of study, significantly the higher numbers of pods were recorded in the treatment in which the preceding rice crop was incorporated with dhaincha green manure (55.9 and 63.0) whereas the lower numbers of pods were registered by no green manure (51.3 and 53.3) to the rice crop. Significantly the higher number of pods and the lower number of pods plant ${ }^{-1}$ were registered at 75 $\mathrm{kg} \mathrm{P}_{2} \mathrm{O}_{5}$ and $45 \mathrm{~kg} \mathrm{P}_{2} \mathrm{O}_{5}$ to kharif rice, respectively in first as well as second year of study. Significantly the higher (56.3 and 63.6) and lower number (50.1 and 53.5) of pods plant $^{-1}$ of blackgram were registered with $100 \%$ RDP and control, respectively in both the years of study. The increase in the pods per plant and number of seeds per pod with the application of phosphorus might be due to the regulatory function of $\mathrm{P}$ in photosynthesis and carbohydrate metabolism in leaves which can be considered to be one of the major factors. The level of phosphorus during the period regulates starch/sucrose ratio in the leaves (source) and the reproductive organs (sink) as stated by Giaqinta and Quebedeaux, (1980).

\section{Seed yield $\left(\mathrm{kg} \mathrm{ha}^{-1}\right)$}

The seed yield of rabi blackgram was significantly higher with dhaincha green manure (869 and $851 \mathrm{~kg} \mathrm{ha}^{-1}$ during first and second years, respectively) and was followed by (863 and $848 \mathrm{~kg} \mathrm{ha}^{-1}$ during first and second years, respectively) sunnhemp incorporation. No green manure to the kharifrice recorded significantly lower (823 and $797 \mathrm{~kg} \mathrm{ha}^{-1}$ ) yield. Significantly higher (876 and $851 \mathrm{~kg} \mathrm{ha}^{-1}$ grain yield in 2015 and 2016) and lower seed yield ( 813 and $801 \mathrm{~kg}$ $\mathrm{ha}^{-1}$ ) were registered with $75 \mathrm{~kg} \mathrm{P}_{2} \mathrm{O}_{5} \mathrm{ha}^{-1}$ and $45 \mathrm{~kg} \mathrm{P}_{2} \mathrm{O}_{5} \mathrm{ha}^{-1}$ phosphorus application to rice crop respectively (Table 2 ).

Significantly the higher $884 \mathrm{~kg} \mathrm{ha}^{-1}$ to $\mathrm{kg} 855$ $\mathrm{ha}^{-1}$ seed yield in first year and second year of study was registered when $100 \%$ RDP was supplied which was closely followed by $50 \%$ of RDP. However, lower seed yield $(803 \mathrm{~kg}$ $\mathrm{ha}^{-1}$ and $796 \mathrm{~kg} \mathrm{ha}^{-1}$ in first and second years, respectively) was recorded with the control. Per cent increase in seed yield due to $100 \%$ RDP over $50 \%$ and control was 13.3 and 26.7 per cent, respectively during first year where as 13.3 and 27.4 per cent more during the second year of experimentation. The increase in the seed yield of succeeding blackgram with phosphorus applied to rice at later stages could be ascribed, to the increased residual available phosphorus which helped in developing profuse root system resulting in increased nutrient uptake, higher drymatter accumulation and translocation of photosynthates from vegetative parts to seeds. The results confirm with the findings of Mehta et al., (2010) and Dekhane et al., (2011). 
Table.1 Growth of blackgram as influenced by green manures and phosphorus levels applied to kharif rice crop and phosphorus doses to rabi blackgram during 2015 and 2016

\begin{tabular}{|c|c|c|c|c|c|c|}
\hline & \multicolumn{2}{|c|}{ Plant height (cm) } & \multicolumn{2}{|c|}{$\begin{array}{c}\text { Drymatter } \\
\text { accumulation }\left(\mathrm{kg} \mathrm{ha}^{-1}\right)\end{array}$} & \multicolumn{2}{|c|}{ Number of pods plant ${ }^{-1}$} \\
\hline & 2015 & 2016 & 2015 & 2016 & 2015 & 2016 \\
\hline \multicolumn{7}{|c|}{ Green manures (M) } \\
\hline Dhaincha & 77.1 & 81.7 & 1852 & 1855 & 55.9 & 63.0 \\
\hline Sunnhemp & 75.5 & 80.4 & 1847 & 1845 & 54.3 & 61.5 \\
\hline $\begin{array}{l}\text { Without green } \\
\text { manure }\end{array}$ & 70.6 & 76.2 & 1774 & 1731 & 51.3 & 53.3 \\
\hline SEm \pm & 0.83 & 0.82 & 18.4 & 18.1 & 0.63 & 0.73 \\
\hline $\mathrm{CD}(\mathrm{P}=0.05)$ & 1.32 & 0.83 & 23.2 & 26.7 & 0.84 & 0.82 \\
\hline CV $(\%)$ & 1.64 & 0.91 & 22.5 & 28.1 & 1.12 & 1.14 \\
\hline \multicolumn{7}{|l|}{ P Levels } \\
\hline $45 \mathrm{~kg} \mathrm{P}_{2} \mathrm{O}_{5} \mathrm{ha}^{-1}$ & 71.2 & 77.4 & 1761 & 1738 & 51.9 & 56.7 \\
\hline $60 \mathrm{~kg} \mathrm{P}_{2} \mathrm{O}_{5} \mathrm{ha}^{-1}$ & 75.6 & 80.1 & 1839 & 1834 & 54.4 & 59.4 \\
\hline $75 \mathrm{~kg} \mathrm{P}_{2} \mathrm{O}_{5} \mathrm{ha}^{-1}$ & 76.3 & 80.8 & 1873 & 1859 & 55.3 & 61.8 \\
\hline SEm \pm & 3.1 & 3.0 & 72 & 71 & 2.0 & 2.8 \\
\hline $\mathrm{CD}(\mathrm{P}=\mathbf{0 . 0 5})$ & 4.3 & 2.6 & 75 & 87 & 2.4 & 2.6 \\
\hline CV $(\%)$ & 4.9 & 2.7 & 68 & 84 & 3.4 & 3.4 \\
\hline \multicolumn{7}{|l|}{$P$ doses } \\
\hline No $P$ & 70.7 & 77.1 & 1769 & 1745 & 50.1 & 53.5 \\
\hline $50 \% P$ & 76.2 & 80.1 & 1842 & 1825 & 55.2 & 60.7 \\
\hline $100 \% P$ & 76.3 & 81.1 & 1862 & 1861 & 56.3 & 63.6 \\
\hline SEm \pm & 5.5 & 5.1 & 5.2 & 5.2 & 5.4 & 6.3 \\
\hline $\mathrm{CD}(\mathrm{P}=0.05)$ & 9.1 & 5.2 & 6.6 & 7.7 & 7.2 & 7.1 \\
\hline CV (\%) & 11.5 & 5.8 & 6.4 & 8.1 & 10.9 & 9.8 \\
\hline \multicolumn{7}{|l|}{ Interaction } \\
\hline \multicolumn{7}{|l|}{ MXL } \\
\hline SEm \pm & 2.33 & 1.41 & 40.1 & 46.2 & 1.31 & 1.41 \\
\hline $\mathrm{CD}(\mathrm{P}=0.05)$ & NS & NS & NS & NS & $\mathrm{NS}$ & NS \\
\hline \multicolumn{7}{|l|}{ MXD } \\
\hline SEm \pm & 2.84 & 1.52 & 39.0 & 48.7 & 2.03 & 1.91 \\
\hline $\mathrm{CD}(\mathrm{P}=0.05)$ & NS & NS & NS & NS & NS & NS \\
\hline \multicolumn{7}{|l|}{ LXD } \\
\hline SEm \pm & 2.82 & 1.52 & 39.0 & 48.7 & 2.02 & 1.91 \\
\hline $\mathrm{CD}(\mathrm{P}=\mathbf{0 . 0 5})$ & NS & NS & NS & NS & NS & NS \\
\hline \multicolumn{7}{|l|}{ MXLXD } \\
\hline SEm \pm & 4.91 & 2.71 & 67.6 & 84.3 & 3.43 & 3.42 \\
\hline $\mathrm{CD}(\mathrm{P}=0.05)$ & NS & NS & NS & NS & NS & NS \\
\hline
\end{tabular}


Table.2 Seed yield $\left(\mathrm{kg} \mathrm{ha}^{-1}\right)$, haulm yield and harvest index (\%) of blackgram as influenced by green manures and phosphorus levels applied to kharif rice crop and phosphorus doses to rabi blackgram during 2015 and 2016

\begin{tabular}{|c|c|c|c|c|c|c|}
\hline & \multicolumn{2}{|c|}{ Seed yield $\left(\mathrm{kg} \mathrm{ha}^{-1}\right)$} & \multicolumn{2}{|c|}{ Haulm yield $\left(\mathrm{kg} \mathrm{ha}^{-1}\right)$} & \multicolumn{2}{|c|}{ Harvest index (\%) } \\
\hline & 2015 & 2016 & 2015 & 2016 & 2015 & 2016 \\
\hline Dhaincha & 869 & 851 & 1362 & 1248 & 41.5 & 42.0 \\
\hline Sunnhemp & 863 & 848 & 1353 & 1273 & 41.2 & 41.2 \\
\hline $\begin{array}{l}\text { Without green } \\
\text { manure }\end{array}$ & 823 & 797 & 1287 & 1153 & 40.8 & 40.1 \\
\hline SEm \pm & 8.3 & 8.3 & 14.0 & 11.6 & 0.33 & 0.14 \\
\hline $\mathrm{CD}(\mathrm{P}=\mathbf{0 . 0 5})$ & 15.6 & 12.6 & 22.1 & 25.4 & NS & 0.5 \\
\hline CV $(\%)$ & 16.6 & 14.7 & 20.0 & 25.5 & 4.2 & 1.7 \\
\hline \multicolumn{7}{|l|}{$P$ levels } \\
\hline $45 \mathrm{~kg} \mathrm{P}_{2} \mathrm{O}_{5} \mathrm{ha}^{-1}$ & 813 & 801 & 1278 & 1177 & 41.1 & 41.1 \\
\hline $60 \mathrm{~kg} \mathrm{P}_{2} \mathrm{O}_{5} \mathrm{ha}^{-1}$ & 866 & 844 & 1352 & 1261 & 41.0 & 41.2 \\
\hline $75 \mathrm{~kg} \mathrm{P}_{2} \mathrm{O}_{5} \mathrm{ha}^{-1}$ & 876 & 851 & 1371 & 1270 & 41.3 & 41.0 \\
\hline SEm \pm & 32 & 32 & 55 & 46 & 0.44 & 0.72 \\
\hline $\mathrm{CD}(\mathrm{P}=\mathbf{0 . 0 5})$ & 51 & 41 & 72 & 83 & NS & NS \\
\hline CV $(\%)$ & 50 & 44 & 60 & 77 & 5.5 & 8.4 \\
\hline \multicolumn{7}{|l|}{ P doses } \\
\hline No P & 803 & 796 & 1282 & 1165 & 40.6 & 41.3 \\
\hline $50 \% \mathrm{P}$ & 867 & 845 & 1349 & 1257 & 41.3 & 41.2 \\
\hline $100 \% \mathrm{P}$ & 884 & 855 & 1370 & 1287 & 41.5 & 40.7 \\
\hline SEm \pm & 5.0 & 5.2 & 5.5 & 5.0 & 0.62 & 0.73 \\
\hline $\mathrm{CD}(\mathrm{P}=\mathbf{0 . 0 5})$ & 9.5 & 7.8 & 8.6 & 10.7 & NS & NS \\
\hline CV $(\%)$ & 10.1 & 9.2 & 7.8 & 10.7 & 7.2 & 9.2 \\
\hline \multicolumn{7}{|l|}{ Interaction } \\
\hline \multicolumn{7}{|l|}{ MXL } \\
\hline SEm \pm & 27.1 & 21.8 & 38.3 & 44.0 & 0.81 & 1.23 \\
\hline $\mathrm{CD}(\mathrm{P}=0.05)$ & NS & NS & NS & NS & NS & NS \\
\hline \multicolumn{7}{|l|}{ MXD } \\
\hline SEm \pm & 28.8 & 25.4 & 34.7 & 44.2 & 1.02 & 1.32 \\
\hline $\mathrm{CD}(\mathrm{P}=\mathbf{0 . 0 5})$ & NS & NS & NS & NS & NS & NS \\
\hline \multicolumn{7}{|l|}{ LXD } \\
\hline SEm \pm & 28.8 & 25.4 & 34.7 & 44.2 & 1.04 & 1.34 \\
\hline $\mathrm{CD}(\mathrm{P}=0.05)$ & NS & NS & NS & NS & NS & NS \\
\hline \multicolumn{7}{|l|}{ MXLXD } \\
\hline SEm \pm & 49.9 & 44.0 & 60.1 & 76.6 & 1.73 & 2.22 \\
\hline $\mathrm{CD}(\mathrm{P}=\mathbf{0 . 0 5})$ & NS & NS & NS & NS & NS & NS \\
\hline
\end{tabular}




\section{Haulm yield $\left(\mathrm{kg} \mathrm{ha}^{-1}\right)$}

Significantly higher haulm yield (1362 and $1248 \mathrm{~kg} \mathrm{ha}^{-1}$ during both years, respectively) of blackgram was recorded when the preceding rice was incorporated with dhaincha green manure which was closely followed by sunnhemp incorporation (1353 and $1273 \mathrm{~kg} \mathrm{ha}^{-1}$ during first and second years, respectively) treatment. Without green manure incorporation plot registered the lower (1287 and $1153 \mathrm{~kg} \mathrm{ha}^{-1}$ ) haulm yield.

Significantly the higher (1371 and $1270 \mathrm{~kg}$ $\mathrm{ha}^{-1}$ haulm yield in 2015and 2016 respectively) and the lower haulm yield (1278 and $1177 \mathrm{~kg} \mathrm{ha}^{-1}$ during both the years) were registered with $75 \mathrm{~kg} \quad \mathrm{P}_{2} \mathrm{O}_{5} \mathrm{ha}^{-1}$ and $45 \mathrm{~kg}$ $\mathrm{P}_{2} \mathrm{O}_{5} \mathrm{ha}^{-1}$ phosphorus application to rice crop, respectively

Significantly the higher (1368 and $1278 \mathrm{~kg}$ ha $^{-1}$ during $1^{\text {st }}$ and $2^{\text {nd }}$ year respectively) haulm yield was registered when 100\% RDP was supplied which was closely followed by $50 \%$ of RDP followed this treatment. However, lower haulm yield (1281and 1167 $\mathrm{kg} \mathrm{ha}^{-1}$ in first and second years, respectively) was recorded with control. The role of phosphorus as part of chlorophyll pigment, its roll in enzymatic reactions is well documented. This might have resulted in higher growth characters, yield attributes and finally the higher haulm yield. Similar reports of increased haulm yield of rabi blackgram at higher doses of phosphorus was also reported by Ghulam (2011)

\section{Harvest index (\%)}

During the $2^{\text {nd }}$ year of study, the green manure incorporation only had a significant influence on harvest index. Significantly the highest harvest index (41.5 and 42.0) recorded with dhaincha green manure incorporation to rice crop which was remained statistically on par with sunnhemp incorporation. The lowest harvest index was obtained with control. No interaction was found to be significant during both years of study.

Similarly, among the $\mathrm{P}$ doses to blackgram, application of 50\% and $100 \%$ RDP proved to be significantly superior to control but both of them did not differ significantly. None of the interactions were not show significant variation in harvest index.

Overall, the field studies conducted for two consecutive years clearly indicated that incorporation of green manures preceding to rice crop and application with $75 \mathrm{~kg} \mathrm{P}_{2} \mathrm{O}_{5} \mathrm{ha}^{-1}$ to kharif rice crop and $100 \%$ RDP to rabi blackgram treatment had a significant influence in increasing productivity and profitability in rice - blackgram sequence. Therefore from this study, it was concluded that application of green manures with $60 \mathrm{~kg}$ $\mathrm{P}_{2} \mathrm{O}_{5}$ ha $^{-1}$ to kharif rice crop and $50 \%$ RDP to succeeding rabi blackgram is the best and the most profitable cropping sequence in the study area.

\section{References}

Ajay, G., and Vinod, K. S. 2006. Studies on the effect of biofertilizers and phosphorus levels on yield and economics of urdbean (Vigna mungo L. Hepper). Legume Research. 29(4):278281.

Dekhane, S. S., H. R.Khafi, A. D.Raj and Parmar, R.M. 2011.Effect of biofertilizer and fertility on yield, protein content and nutrient uptake of cowpea. Legume Research. 34(1):5154.

Deo, C., and Khaldelwal, R. B. 2009.Effect of $\mathrm{P}$ and $\mathrm{S}$ nutrition on yield and quality of chickpea (Cicer arietinum L.).Journal of Indian Society Soil Science. 57(3): 352- 
356.

Ghulam, A., Z. Abbas,M. Aslam, M. AsmatUllah Malik, Ishaque and Hussain, F. 2011. Effects of organic and inorganic fertilizers on mungbean (Vigna radiata $(\mathrm{L}$.$) ) yield under arid$ climate. International Research Journal of Plant Science. 2:94-98.

Giaquinta, R.T., and Quebedeaux, B. 1980. Phosphate induced changes in assimilate partitioning in soybean leaves during pod filling. Plant Physiology.65:119.

Hanumanthappa, M., and Hosamani, S. A. 1989.Response of soybean varieties to phosphorus under rainfed conditions.
M.Sc. (Ag.) Thesis submitted to University of Agricultural Sciences, Bangalore.

Kundu, S., Kamath, M. B and Goswami, N. N. 1986.Evaluation of residual effect of phosphate in rice-wheat-greengram-rice cropping sequence using $32 \mathrm{P}$ as a tracer. Journal of Nuclear and Agricultural Biology. 15 (2): 115-119.

Mehta, R. S., B. S. Patel, S. S. Meena and Meena, R.S. 2010. Influence of nitrogen, phosphorus and biofertilizers on growth characters and yield of fenugreek (Trigonella foenungreacum L.). Journal of Spices and Aromatic Crop. 19 : 23-28.

\section{How to cite this article:}

Anny Mrudhula, K., Ch. PullaRao, B. Venkateswarlu, P. R. K Prasad and Ashoka Rani. Y. 2020. Performance of Green Manures and Phosphorus Levels in Rice-Blackgram Cropping Sequence. Int.J.Curr.Microbiol.App.Sci. 9(06): 522-528.

doi: https://doi.org/10.20546/ijcmas.2020.906.067 